\title{
SHAPING TEAT SUCTION FORCES OF LINERS WITH VARIED STRUCTURE OF RUBBER CORE
}

\author{
Marian Wiercioch*, Adam Luberański, Krzysztof Lejman, Małgorzata Fugol, \\ Hubert Prask
}

Institute of Agricultural Engineering, University of Life Sciences in Wroclaw

${ }^{*}$ Corresponding author: e-mail: marian.wiercioch@upwr.edu.pl

\begin{tabular}{|c|c|}
\hline ARTICLE INFO & ABSTRACT \\
\hline $\begin{array}{l}\text { Article history: } \\
\text { Received: January } 2019 \\
\text { Received in the revised form: } \\
\text { February } 2019 \\
\text { Accepted: March } 2019 \\
\end{array}$ & $\begin{array}{l}\text { A liner is the only part of the milking unit which has a direct contact } \\
\text { with a cow's teat. It ensures a correct circulation of body liquids in } \\
\text { a teat with its suitable massage and creates conditions for a teat to } \\
\text { open and milk to flow out and maintains a milking cup on a teat. The } \\
\text { result of the last task is generation of a suction force that sucks a teat }\end{array}$ \\
\hline $\begin{array}{l}\text { Key words: } \\
\text { mechanical milking, } \\
\text { milking cup, } \\
\text { liner, } \\
\text { teat suction force }\end{array}$ & $\begin{array}{l}\text { into a liner. During milking, when a cup is placed on a teat, counter } \\
\text { forces are generated that try to remove a liner from a teat and forces } \\
\text { that cause that a teat moves up to a liner producing a phenomenon of } \\
\text { "a climbing cup". Forces that tend to separate a teat from a liner } \\
\text { depend on the mass of a milking cup set and the value of the friction } \\
\text { force. A counter force that tends to suck a teat into a liner is propor- } \\
\text { tional to the level of negative pressure in a liner and the surface of } \\
\text { cross-section of a teat that is subjected to negative pressure. We } \\
\text { should also assume that also the structure of a liner will influence this } \\
\text { force. The paper presents results of the laboratory tests on the impact } \\
\text { of the shape of the cross-section of a rubber core and construction } \\
\text { solutions of liners on the vacuum force of a liner when a teat is sucked } \\
\text { into a teat chamber. Eight liners, popular in milking machines used in } \\
\text { our country were used in the tests. Various penetrations of a teat }(50 \text {, } \\
62 \text {, } 75 \text { and } 100 \text { mm), working pressure ( } 25-55 \mathrm{kPa}) \text { and a working } \\
\text { stage of the milking cup were additional variables. In order to deter- } \\
\text { mine whether and what is the degree of the impact of variability } \\
\text { sources on shaping the suction forces of a liner, a static processing of } \\
\text { results was carried out using a multi-variance analysis. It was proved } \\
\text { that at the significance level of } \alpha=0.05 \text {, the source of variability assu- } \\
\text { med in the experiment in the form of the liner shape, negative pressure } \\
\text { and penetration affected the analysed sizes, i.e. Average values of } \\
\text { suction forces in the suction phase }\left(\mathrm{F}_{\mathrm{ws}}\right) \text { and massage phase }\left(\mathrm{F}_{\text {wm }}\right) \text {. The } \\
\text { investigation of the impact of the rubber core part on the determined } \\
\text { values of the suction force in the function of variable negative pressu- } \\
\text { re proved that at teat penetration of } 50 \text { and } 62 \text { mm (the most popular } \\
\text { lengths of teats in milked cows), the lowest suction force was obse- } \\
\text { rved in case of a liner with a triangular cross-section, slightly bigger } \\
\text { with a square cross-section and the highest suction force is generated } \\
\text { by round and oval liners. }\end{array}$ \\
\hline
\end{tabular}




\section{Introduction}

Performance of a liner in milking machines depends greatly on physical and mechanical properties of a material of which it was made, structural solution of a head and rubber core i.e. elements that act on a teat (Harms, 2009; Mayntz, 1981). Moreover, a liner should be made of a material admitted to the contact with milk, should be elastic and strong, its walls should be smooth, and it should be well adhesive at optimal tension in a cylinder (Boast et al., 2004; Rasmussen and Madsen, 2000). Regarding functionality, a liner is responsible for teat protection against negative pressure, ensuring a correct circulation of body liquids in a teat by its relevant massage and creation of conditions for the opening position of a teat and for milk to flow out, and to maintain a milking cup on a teat. The result of the last task is generation of a suction force that sucks a teat into a liner. It is emphasised in the literature (Mayntz, 1981; Nordegren, 1980; Szlachta, 1986) that during milking, when a cup is placed on a teat, counter forces are generated that try to remove a liner from a teat and forces that cause that a teat moves further to a liner producing a phenomenon of "a climbing cup". This function of a liner is directly related to a negative impact of machine milking on the health of a milk gland. In case of thin and long teats, they are sucked deep to a teat chamber, so that the end of a teat is in the zone where it can be protected against negative pressure, because a liner is closed in the massage phase below the teat top.

Forces that tend to separate a teat from a liner depend on the mass of the milking cup set and the value of the friction force. Numerous papers indicate a positive impact of the friction force on a liner on stable maintenance of a milking cup on a teat, especially protection of excessive suction of a teat into a teat chamber (Mayntz, 1981; Nordegren, 1980; Szlachta, 1986). A counter force that tends to suck a teat into a liner is proportional to the level of negative pressure in a liner and the surface area of the cross-section of a teat that is subjected to negative pressure. Too extensive suction forces may strain a delicate structure of a teat which may result in intensive congestion of a teat. The above conclusions were formulated based on the research results when only liners with a round cross-section of the rubber core were used for milking. In general, this force is higher than the force referred to the mass, when a liner is open but smaller when it is closed.

The available branch literature includes papers (Szlachta and Wiercioch, 1987a; Wiercioch and Szlachta, 1993), where the research results of the suction force of traditional liners with a round cross-section of the rubber core were presented, but there is no information concerning liners with a multi-angle (triangular, square) shape of the rubber core. Information provided by producers of this type of triangular liners (www.1; www.2; $\underline{\text { www.3 }}$ ) indicate their favourable, less intensive mechanical teat loading, better adhesion and more delicate milking. Additionally, according to the producer, the teat top which is the most sensitive part, is subjected to lower loads since in this area negative pressure is more stable. Observations concerning the stability of negative pressure entirely correspond with the results of research by Luberański et al., (2010). As a result, in a teat channel, keratin production is reduced, which limits the risk of cornification in the area of its opening (hyperkeratosis). Simultaneously, a risk of eversion of the mucosa membrane of the teat channel is limited.

Gedymin (2005, 2006), Gedymin and Chmielewski (2008) as well as Krzyś et al., (2010) criticise the functioning of a triangular liner in the aspect of their tightness (precision) and liner closing in the massage phase indicating its not precise closing. These authors say that a several times lower tightness of closing of these liners in the massage phase in 
Shaping teat suction forces...

comparison to the results of flat-closing liners - including a square one (Gedymin 20052006), results from a higher number of fissures and their bigger sizes - a channel, by which negative pressure may freely move towards a teat. Simultaneously, the same authors indicate that this type of liners better massage teats and the massage itself, due to their construction, is directed mainly towards the end of a teat. They almost say that the basic purpose of implementation of triangular liners to a milking practice seems to be a possibility of obtaining even bigger massaging pressure than in the popular round liners, while other parameters of these liners do not indicate their better cooperation with a teat (Gedymin and Chmielewski, 2008). These suggestions also partially confirm the research results by Luberański et al., ((2009) and Wiercioch et al., (2010).

Liners with triangular and square profiles more often offered by popular producers of milking machines are applied in national milking units. Some of them- vented liners, were additionally equipped with a nozzle placed in the head flange, providing small amounts of air which ensures their favourable impact on a teat and the milk quality (Rasmussen et al., 2006; Vetter et al., 2014). This may result from a more stable working pressure with smaller fluctuations, which was observed by Wiercioch et al., (2016) during the tests on milking units with various systems of air supply to a milking unit. As a result, milk removal is more efficient, teats stay dry and the risk of injury, inter alia, of hyperkeratosis, of teats gets reduced (www.1; www.2; www.3).

\section{The objective of the paper}

The objective of the paper was to determine the impact of the rubber core of liners structure and selected elements of their construction on the values of the force that sucks a teat into a teat chamber in the suction and massage phase including changes of working negative pressure and teat penetration. Due to a significant impact of liners on a teat, they are combined with standard cylinders recommended by their producers to each type of a liner.

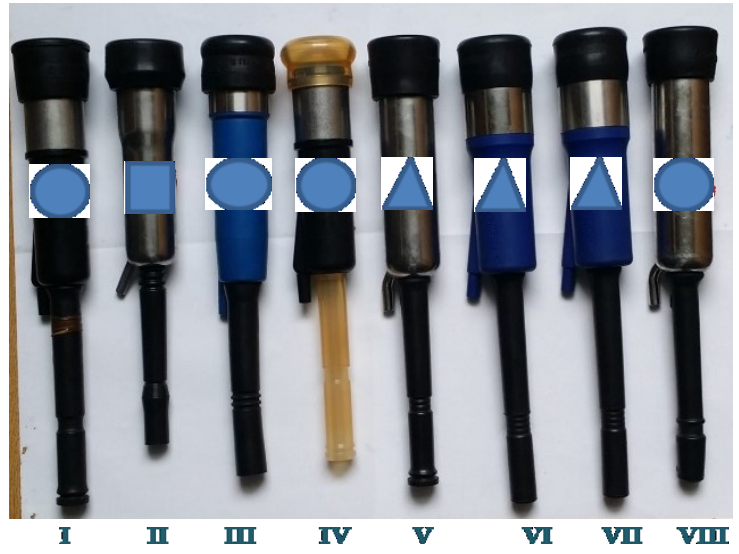

Figure 1. Milking cups with liners, which were used in tests: I - HARMONY, II - SH 3426 028, III - UNIFLOW 2, IV - silicone 964420-80, V - TLC-A5, VI - IP-10U, VII - IP-10U vented, VIII - 92832601 


\section{Object, scope and method of research}

In order to perform the objective of the paper and to compare the impact of the liner construction elements on the teat suction forces, 8 liners were selected for tests (Fig.1) the characteristics of which was presented in table 1 .

Table 1.

Characteristics of liners used in tests

\begin{tabular}{lcclcc}
\hline $\begin{array}{l}\text { Liner } \\
\text { symbol }\end{array}$ & Liner type & $\begin{array}{c}\text { Cross-section } \\
\text { of the rubber } \\
\text { core of a liner }\end{array}$ & Material & $\begin{array}{c}\text { Suction force } \\
\text { of a liner } \\
(\mathrm{N})\end{array}$ & $\begin{array}{c}\text { Cup } \\
\text { weight } \\
(\mathrm{g})\end{array}$ \\
\hline I & Harmony & Round & Rubber & 53 & 270 \\
II & SH 3426028 & Square & Rubber & 60 & 400 \\
III & UNIFLOW 2 & Oval & Rubber & 50 & 270 \\
IV & $964420-80$ & Round & Silicone & 46 & 238 \\
V & TLC-A5 & Triangular & Rubber & 53 & 362 \\
VI & IP-10 U & Triangular & Rubber & 72 & 380 \\
VII & IP-10 U vented & Triangular & Rubber & 70 & 388 \\
VIII & 92832601 & Round & Rubber & 55 & 520 \\
\hline
\end{tabular}

Liners used in the tests had varied cross-sections of a rubber core (rounded, oval, triangular and square) were made with various materials (from rubber and silicone) and one of the liners (VII) was equipped with a nozzle that supplies air to the milking cup (vented liner). Tests were carried out in three measuring blocks. To compare the rubber core shape on the suction force, 4 liners (II, III, V and VII) were selected, made of one material (rubber) differing with a cross-section of the core. In order to determine the impact of the working material (rubber, silicone) on the suction force of a teat, two liners were used (I and IV) with a round cross-section and similar dimensions. The impact of the structural solution of liners on the vacuum force was determined for two types IP-10U (VI and VII), out of which one (VII- vented liner) was equipped with a nozzle (located in the liner head) that supplies atmospheric air to a milking cup.

The tests were carried out in a milking laboratory of the Institute of Agricultural Engineering in Wroclaw on a test stand, the schematic representation of which and a measurement system were presented in figure 2. Technology of measurement of the suction force consisted in supply of the constant negative pressure to the teat chamber and variable pressure to the interwall chamber of a milking cup. An artificial teat with a conical shape was used in measurements. Its dimensions were selected based on the zoometric research results performed by Szlachta and Wiercioch (1987b). For determination of the suction force, negative pressure of $25,30,35,40,45,50$ and $55 \mathrm{kPa}$ and artificial teat penetration of 50 , 
Shaping teat suction forces...

62,75 and $100 \mathrm{~mm}$ were applied. A change in teat penetration was obtained with the use of distance bushings with varied heights at the junction of the liner head and a teat. A slide and pneumatic pulsator with pulsation of 60 cycles per minute and coefficient of the pulsator $60.5 \%$ controlled the work of a milking cup. Measurements of the vacuum force were carried out with HBM sensor type S2 (measurement scope 0-200 N) class 0.05 and changes of negative pressure in the teat chamber and short pulsation conduit were made with a current pressure transducer SML (ADC - Eltek) class 0.25\% (measurement scope 0-60 kPa). Signals from transducers were recorded by a recorder composing a base NIcDAQ 9174 equipped with two current modules NIcDAQ 9203 and one voltage NIcDAQ 9237.

a)

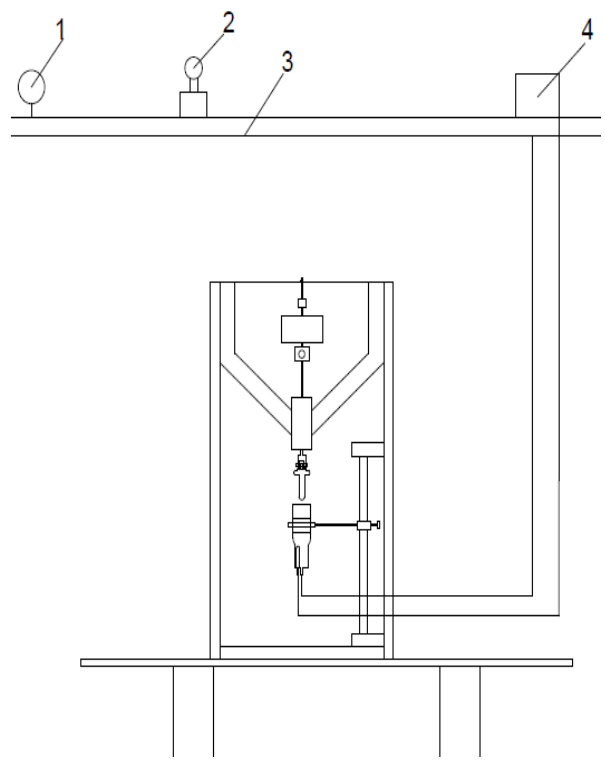

b)

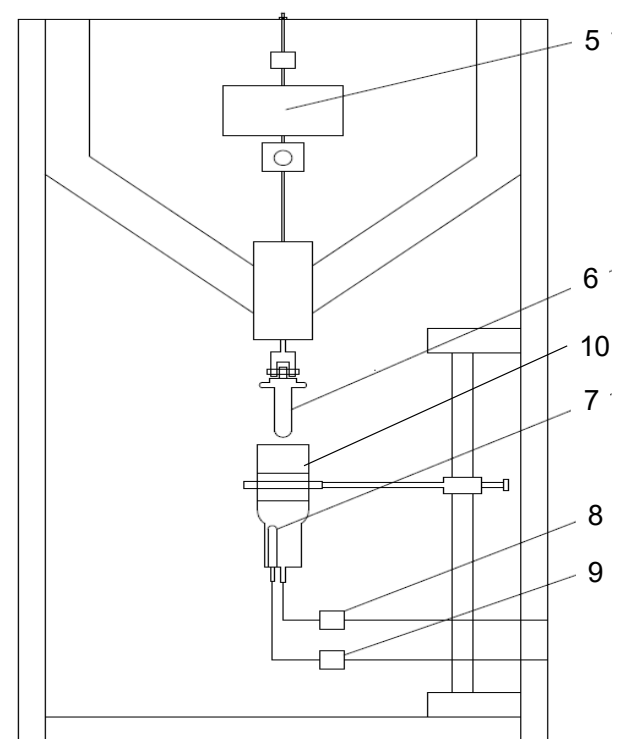

Figure 2. General schematic representation of a stand (a) and measurement system (b): 1 -vacuometer, 2 - negative pressure control valve, 3 - negative pressure pipe, 4 - pulsator, 5 -suction force sensor by HBM, 6 - artificial teat, 7 - milking cup - liner, 8 - negative pressure sensor in teat chamber 9 - negative pressure sensor in pulsator chamber, 10 - distance bushing

Recording of signals measured with sensors took place with $400 \mathrm{~Hz}$ frequency directly at the computer disc according to a configuration defined in the application "Symulacja", (Luberański et al., 2013). Then, the registered data were processed in Excel program. 


\section{Research results}

Multi-variance analysis with interactions between the variability sources (Table 2) made with the statistic application packet Statgraphics 6.0, showed at the significance level of $\alpha=0.05$, the impact of all independent variables of the experiment except for the interaction of negative pressure with penetration $\left(P P_{e}\right)$ on the determined suction forces at the suction phase $F_{w s}$ and massage phase $F_{w m}$. The fact that the obtained results clearly indicate a highly statistically significant differences of the analysed vacuum forces for liners, variable negative pressure and teat penetration, should be emphasised.

The preliminary assessment of teat suction forces in the investigated liners indicates considerable diversity of their values due to the phase of operation of a milking cup. Higher values, by approx. 10\% were determined in the phase, when a liner was open (suction phase). It was reported that the courses of relations of suction forces in the function of negative pressure for both phases of operation of a liner, although they differ with regard to values, on diagrams assume similar (or identical) inclination and location. Thus, the paper analyses and compares suction forces in the suction phase.

Table 2.

Results of multi-variance analysis of the impact of independent variables in experiment on measured suction forces in the suction phase $F_{w s}$ and in the massage phase $F_{w m}$

\begin{tabular}{|c|c|c|c|c|c|c|c|}
\hline \multirow[b]{2}{*}{$\begin{array}{l}\text { Measured } \\
\text { forces }\end{array}$} & \multirow[b]{2}{*}{$\begin{array}{l}\text { Variability } \\
\text { source }\end{array}$} & \multirow[b]{2}{*}{$\begin{array}{l}\text { Liner } \\
\text { Gs }\end{array}$} & \multirow[b]{2}{*}{$\begin{array}{c}\text { Negative } \\
\text { pressure } \\
\text { systemic } \\
P\end{array}$} & \multirow[b]{2}{*}{$\begin{array}{l}\text { Penetration } \\
\text { of liner } \\
\quad P e\end{array}$} & \multicolumn{3}{|c|}{$\begin{array}{l}\text { Interaction between } \\
\text { variability sources }\end{array}$} \\
\hline & & & & & $G s P$ & GsPe & $\begin{array}{c}\text { Vacuum } \\
\text { force in } \\
\text { the } \\
\text { suction } \\
\text { phase } F_{w s}\end{array}$ \\
\hline \multirow{3}{*}{$\begin{array}{l}\text { Vacuum force } \\
\text { in the suction } \\
\text { phase } F_{w s}\end{array}$} & $\begin{array}{c}\text { Number of } \\
\text { freedom degre- } \\
\text { es }\end{array}$ & 7 & 6 & 3 & 42 & 21 & 18 \\
\hline & $\begin{array}{c}\text { Significance } \\
\text { level } \alpha\end{array}$ & 0.000 & 0.000 & 0.000 & 0.000 & 0.000 & 0.287 \\
\hline & F test value & 169.944 & 1271.140 & 107.099 & 2.138 & 96.481 & 1.180 \\
\hline \multirow{2}{*}{$\begin{array}{l}\text { Suction force } \\
\text { in the massage } \\
\text { phase Fwm }\end{array}$} & $\begin{array}{l}\text { Significance } \\
\text { level } \alpha\end{array}$ & 0.000 & 0.000 & 0.000 & 0.019 & 0.000 & 0.000 \\
\hline & F test value & 227.380 & 1049.821 & 79.418 & 1.640 & 86.895 & 3.854 \\
\hline
\end{tabular}

Figure 3 presents relations of the suction forces of liners with varied cross-sections of a rubber core for the suction phase in the function of variable negative pressure at various penetrations of a teat. According to diagrams, for all liners, these relations have a linear nature, and the increase of the suction force is directly proportional to the increasing negative pressure. With the lowest negative pressure of $25 \mathrm{kPa}$, the suction forces values for the investigated liners are within $5-15 \mathrm{~N}$ and for the highest level of negative pressure $(55 \mathrm{kPa})$ are within 22 to ca. $35 \mathrm{~N}$. For extreme changes of values of negative pressure from 2.5 to 5 times increase of the suction force takes place. For the range of negative pressure recom- 
Shaping teat suction forces...

mended for mechanical milking units including a milking system (to a can, to a top or bottom milk pipe) its change from the level of $40 \mathrm{kPa}$ to $48 \mathrm{kPa}$ results in ca. $35 \%$ higher suction force. Thus, we may assume that milking systems with a recommended lower negative pressure (milking to a can and to a bottom milk pipe) a little more delicately affect the milked teat.

The relations presented in figure 3 show that at all penetrations, the lowest courses on diagrams assume the relations determined for triangular V and square II rubber cores and the highest for oval ones III. A round liner VIII for which a course at the teat length 50 and $62 \mathrm{~mm}$ is similar as for oval liner III cooperates with a teat in a slightly different manner and with longer teats $(75$ and $100 \mathrm{~mm}$ ) vacuum forces are generated at a level similar to the values determined for triangular $\mathrm{V}$ and square II liners.
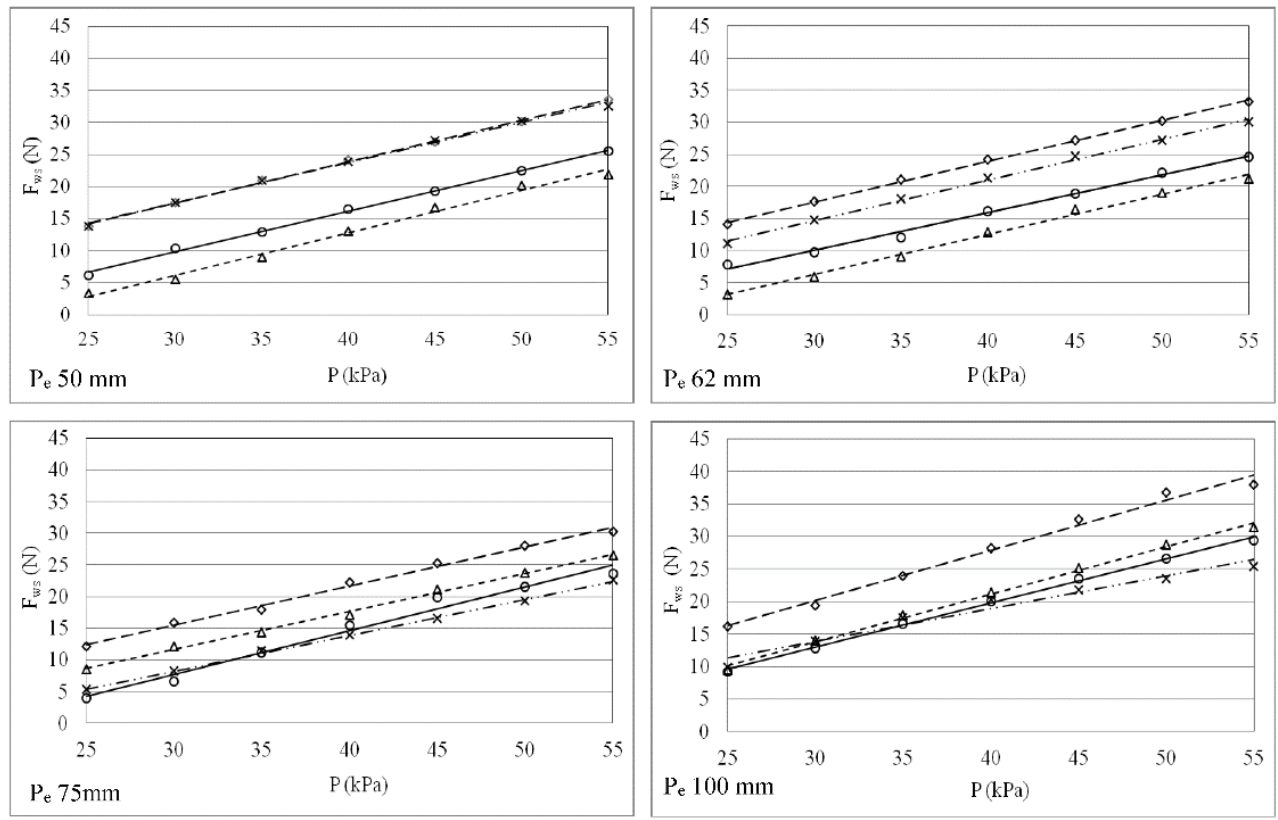

- II $\quad---\cdot$ III $-\cdots \cdot-\cdot$ V $-\cdot \cdot-\cdot$ VIII

Figure 3. The impact of negative pressure $P$ on vacuum forces in suction phase $F_{w s}$ in liners with varied cross sections of rubber core II (square), III (oval), V (triangular) and VIII (round) at varied penetration $P_{e}$

Comparing the values of the suction force for triangular and square liners in comparison to a round liner within a range of recommended negative pressure for mechanical milking units (i.e. $40-48 \mathrm{kPa}$ ) and for penetration of teats that the most often occur in milked cows $(50-62 \mathrm{~mm})$ it was concluded that these values are more favourable (lower) for a triangular and square liner respectively by ca. $10 \mathrm{~N}$ and 6-8 $\mathrm{N}$. The research results suggest that round 
liners (popular in milking) more aggressive than triangular ones and square affect a teat. As a result, one may expect a lower teat congestion which is observed during milking of cows with units equipped with triangular and square liners.

The impact of material, of which a liner is made (rubber - I, silicone - IV) on the suction force acting on a teat with varied length at variable negative pressure values are presented in figure 4. Presented relations have a rectilinear nature in which the increase of negative pressure is accompanied by a proportional increase of the suction force. At the lowest negative pressure applied in measurements $(\mathrm{P}=25 \mathrm{kPa})$, values of these forces are within 5-10 $\mathrm{N}$ at penetrations 52, 60 and $100 \mathrm{~mm}$ and 10-15 $\mathrm{N}$ for the teat length of $75 \mathrm{~mm}$ and at the highest negative pressure $(55 \mathrm{kPa})$ they are within $30-35 \mathrm{~N}$ regardless the applied teat penetration. At all penetrations except for the shortest $\left(\mathrm{P}_{\mathrm{e}}=50 \mathrm{~mm}\right)$ generated suction forces determined at variable negative pressure within $25-55 \mathrm{kPa}$, are by ca. $4-5 \mathrm{~N}$ lower for a silicone liner IV than for a rubber liner (black) I.
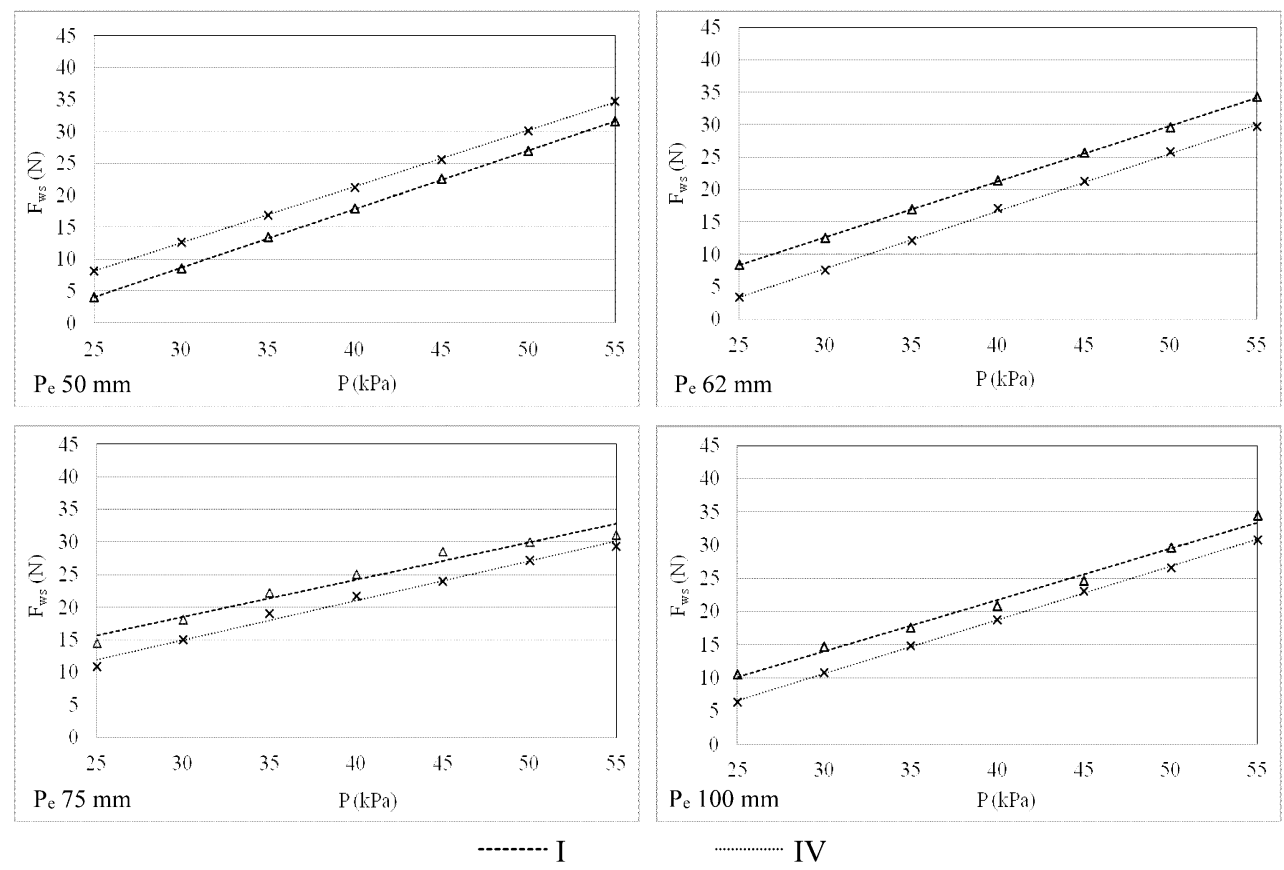

IV

Figure 4. The impact of negative pressure $P$ on suction forces in suction phase $F_{w s}$ in liners made of rubber (black) I and silicone IV at variable penetration Pe

A reverse system of relations of suction forces in the function of negative pressure at the shortest penetration of $50 \mathrm{~mm}$ (Fig. 4) for the investigated liners may result from too small surface of adjusting a teat in case of a silicone liner and from the material properties, mainly a lower friction rate. 
Shaping teat suction forces...

To determine the impact of the structural solution of a liner in the form of a vent system, on the suction force of a liner, two triangular liners type IP-10U (VI and VII) were used; one of them (VII-vented liner) was equipped on arrival with a nozzle placed in the liner head, that introduced small amounts of air to a milking cup. As it was presented in the review of the state of knowledge, this solution enables more efficient milk release, it maintains teats dry during milking and also reduces a risk of teat injuries (www.1; www.2; www.3). Figure 5 presents relations of the suction forces of liners type IP-10U (VI-non vented and VII - vented) in the function of varied negative pressure at variable negative pressure at various penetrations of a teat. Similarly, as in case of previous cases where the impact on the suction force of a liner in the suction phase Fws, cross-section of a rubber core and the material type also courses of relation $F_{w s}$ in the function of variable negative pressure determined for a structural solution of a liner have an increasing rectilinear nature.
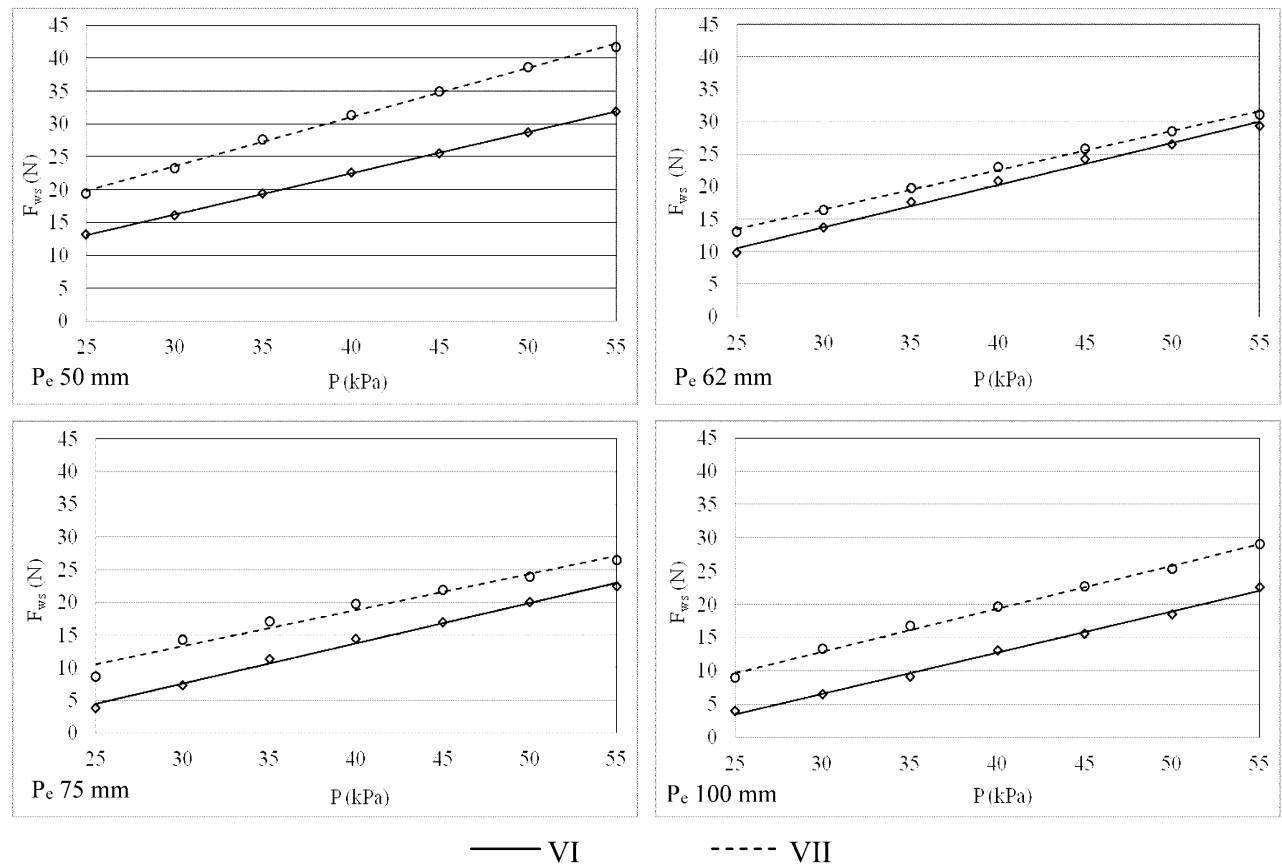

Figure 5. Impact of under pressure $P$ on suction forces in the suction phase Fws in liners type P-10U (VI-non-vented and VII-vented) at variable penetration $P_{e}$

In this case we can notice a trend that an explicit decrease of the suction force takes place in relation to its increasing penetration which did not occur in previous analysed measurement blocks. Relations presented in figure 5 show that at all penetrations, higher suction forces are generated by a vented liner VII. They are higher in comparison to forces 
determined for non-vented liner VI at the teat length of $\mathrm{P}_{\mathrm{e}}=50 \mathrm{~mm}$ by ca. $10 \mathrm{~N}, \mathrm{P}_{\mathrm{e}}=62 \mathrm{~mm}$ by ca. $3 \mathrm{~N}, \mathrm{P}_{\mathrm{e}}=75 \mathrm{~mm}$ by ca. $6 \mathrm{~N}$ and $\mathrm{P}_{\mathrm{e}}=100 \mathrm{~mm}$ by ca. $8 \mathrm{~N}$.

\section{Conclusions}

1. Multi-variance analysis proved that at the significance level of $\alpha=0.05$, the sources of variability assumed in the experiment in the form of the liner type, negative pressure and penetration, affected the analysed average values of the suction forces in the suction phase $\left(\mathrm{F}_{\mathrm{ws}}\right)$ and massage phase $\left(\mathrm{F}_{\mathrm{wm}}\right)$.

2. The working phase of a milking cup has a significant impact on the suction force. In the suction phase, the suction force for all analysed cases was ca. by $10 \%$ higher than in the massage phase.

3. The studies on the impact of a shape of the cross-section of the rubber core on the determined values of the suction forces in the function of a variable negative pressure show that at shorter penetrations of a teat, the lowest suction force was reported in a triangular liner and the highest in case of round and oval liners. The course of the relations for square liners is at a slightly higher level than in triangular ones.

4. The value of negative pressure has a decisive impact on the size of the suction force that sucks a teat into a teat chamber. A change in the negative pressure from $25 \mathrm{kPa}$ to 55 $\mathrm{kPa}$ resulted in a growth of the suction force. For example, for Harmony (I) liner at penetration of $62 \mathrm{~mm}$ for a suction phase, the suction force at the negative pressure of 25 $\mathrm{kPa}$ was $8.20 \mathrm{~N}$ while at negative pressure of $55 \mathrm{kPa}$ this force was at the level of 34.31 $\mathrm{N}$.

5. Material from which the liner was made influences the suction force. A silicone liner generates a lower by approx. 4-5 N suction force than a rubber liner (black) for the entire range of negative pressure changes.

6. IP-10U liner with a special nozzle that supplies air to a teat chamber generates a higher suction force than a liner of the same type without a nozzle. This difference was 3-10 N depending on the penetration and varied value of negative pressure.

\section{References}

Boast, D., Hale M., Turner, D., Hillerton, E., Middleton, N., Ohnstad, I. (2004). Variation in the rubber chemistry and dynamic mechanical properties as liners age. Bulletin of the IDF, 388 . 65-74.

Gedymin, M. (2005). Wpływ zmiany kształtu trzonu gumy strzykowej z okragłego na kwadratowy na jej oddziaływanie na strzyk. XI Międzynarodowa Konferencja Naukowa: Problemy Intensyfikacji Produkcji Zwierzęcej z uwzględnieniem ochrony środowiska i standardów UE. Materiały konferencyjne, IBMER Warszawa. 133-136.

Gedymin, M. (2006). Wpływ zmiany kształtu trzonu gumy strzykowej z okrągłego na trójkątny na jej oddziaływanie na strzyk. XII Międzynarodowa Konferencja Naukowa: Problemy Intensyfikacji Produkcji Zwierzęcej z uwzględnieniem ochrony środowiska i standardów UE. Materiały konferencyjne, IBMER Warszawa, 123-129.

Gedymin, M., Chmielewski A. (2008). Nowe rozwiązania w konstrukcji gum strzykowych. Inżynieria Rolnicza, 4(102), 289-297.

Harms, J. (2009). Automatisches Melken - Stand der Technik und Entwicklungstendenzen. ARTSchriftenreihe, 9, 105-113. 
Shaping teat suction forces...

Krzyś, A., Luberański, A., Szlachta, J., Wiercioch M. (2010). Geometryczne parametry nowoczesnych gum strzykowych podczas interakcji ze strzykiem. Inżynieria Rolnicza, 1(119), 273-279.

Luberański, A., Krzyś, A., Szlachta, J. (2009). Analiza warunków ciśnieniowych w aparacie udojowym przy zastosowaniu gum strzykowych o różnym przekrojach poprzecznych części trzonowych. Inżynieria Rolnicza, 5(114), 169-176.

Luberański, A., Szlachta, J., Krzyś, A., Wiercioch M. (2010). Wahania podciśnienia w aparatach udojowych z gumami strzykowymi o kwadratowym, trójkątnym oraz owalnym profilu części trzonowej. Inżynieria Rolnicza, 2(120), 33-41.

Luberański, A., Pruski, K., Wiercioch, M. (2013). Metoda komputerowego wspomagania obliczeń ciśnieniowych parametrów mechanicznego doju i nacisków masujących strzyk. Inżynieria Rolni$c z a, 3(146), 235-242$.

Mayntz, Ch.M. (1981). Über den Einfluss Ausgewählter masse des Zizengumikopfes auf Merkamle der Melkarbeit. Dissertation. Hohenheim.

Nordegren, S.A. (1980). Cyclic vacuum fluctuations in milking machines. Dissertation. Hohenheim.

Rasmussen, M.D., Madsen, N.P. (2000). Effects of milkline vacuum, pulsator airline vacuum, and cluster weight on milk yield, teat condition, and udder health. Journal of Dairy Science, 83, 77-84.

Rasmussen, M.D., Wiking, L., Bjerring, M., Larsen, H.C. (2006). Influence of air intake on the concentration of free fatty acids and vacuum fluctuations during automatic milking. Journal of Dairy Science, 89, 4596-4605.

Szlachta, J. (1986). Studia nad wybranymi elementami budowy i użytkowania aparatu udojowego. Zeszyty Naukowe AR Wroclaw, Rozprawy, 58, ISSN 0209-1321.

Szlachta, J., Wiercioch, M. (1987a). Określenie skłonności wsysania strzyka do komory kubka udojowego. Zeszyty Naukowe AR we Wrocławiu, Rolnictwo XLVI, 164, 91-96.

Szlachta, J., Wiercioch, M. (1987b). Opracowanie wzorców sztucznych strzyków krowich do badań laboratoryjnych parametrów gum strzykowych. Zeszyty Naukowe AR we Wrocławiu, Rolnictwo XLVI, 164, 97-105.

Wiercioch, M., Szlachta, J. (1993). Analiza sił wciągania strzyka do zmodyfikowanych gum strzykowych. Problemy Inżynierii Rolniczej, 1(1), 75-81.

Wiercioch, M., Luberański, A., Balbierz, K., Krzyś A. (2010). Wpływ przekroju trzonowej części gumy strzykowej na przebieg procesu doju krów. Inżynieria Rolnicza, 2(120), 271-278.

Wiercioch, M., Luberański, A., Krzyś, A., Skalska, D., Szlachta, J. (2016). Impact of the system of air supply to a milking unit on selected parameters of milking machine operation. Agricultural Engineering, Vol.20, 3(159), 195-205.

Vetter, A., van Dorland, H.A., Youssef, M., Bruckmaier, R.M. (2014). Effects of a latency period between pre-stimulation and teat cup attachment and periodic vacuum reduction on milking characteristics and teat condition in dairy cows. Journal of Dairy Research, 81, 107-112.

www.1 http://www.milkrite.com/US/Products/impulse_air.htm, dostęp 10.04.2018.

www.2 http://www.apagro.pl/HeroGraf/do_pobrania/top_agrar1.jpg, dostęp 10.04.2018.

www.3 http://www.apagro.pl/HeroGraf/do_pobrania/top_agrar2.jpg, dostęp 10.04.2018. 
M. Wiercioch, A. Luberański, K. Lejman, M. Fugol, H. Prask

\title{
KSZTAŁTOWANIE SIE SIL WCIĄGANIA STRZYKA DO GUM STRZYKOWYCH O RÓŻNEJ KONSTRUKCJI CZECŚCI TRZONOWEJ
}

\begin{abstract}
Streszczenie. Guma strzykowa jest jedynym elementem aparatu udojowego, który ma bezpośredni kontakt ze strzykiem dojonej krowy. Ma ona za zadanie zapewniać prawidłowy obieg płynów ustrojowych w strzyku przez odpowiedni jego masaż oraz stworzenie warunków do przyjęcia przez strzyk „pozycji otwarcia” i wypływu mleka oraz do prawidłowego utrzymywania się kubka udojowego na strzyku. Efektem ostatniego zadania jest generowanie siły wciągania strzyka do gumy strzykowej. Podczas doju, kiedy kubek założony jest na strzyku, pojawiają się przeciwstawne siły starające się usunąc gumę ze strzyka jak również powodujące ruch strzyka głębiej do gumy wywołując zjawisko „wspinania się kubka". Tendencja sił do separacji strzyka i gumy jest uzależniona od masy zestawu kubka udojowego i wielkości siły tarcia. Siła przeciwna mająca tendencję do wciągania strzyka do gumy strzykowej jest proporcjonalna do poziomu podciśnienia w gumie strzykowej i powierzchni przekroju strzyka wystawionego na działanie podciśnienia. Należy przypuszczać, że również konstrukcja gumy strzykowej będzie wpływała na tę siłę. W pracy przedstawiono wyniki badań laboratoryjnych wpływu kształtu przekroju trzonu oraz rozwiązań konstrukcyjnych gum strzykowych na siłę wciągania strzyka do komory podstrzykowej kubka udojowego. W badaniach użyto osiem gum strzykowych powszechnie stosowanych w dojarkach użytkowanych w kraju. Dodatkowymi zmiennymi były różne penetracje strzyka $(50,62,75$ i $100 \mathrm{~mm})$, podciśnienia robocze $(25-55 \mathrm{kPa})$ i faza pracy kubka udojowego. W celu określenia, czy i na jakim poziomie poszczególne źródła zmienności wpływają na kształtowanie się sił wciągania strzyka przeprowadzono statystyczną obróbkę wyników, używając wieloczynnikowej analizy wariancji. Wykazano na poziomie istotności $\alpha=0.05$, że przyjęte w doświadczeniu źródła zmienności w postaci kształtu gumy strzykowej, podciśnienia i penetracji miały wpływ na analizowane wielkości, tj. średnie wartości sił wciągania $\mathrm{w}$ fazie ssania $\left(\mathrm{F}_{\mathrm{ws}}\right)$ i w fazie masażu $\left(\mathrm{F}_{\mathrm{wm}}\right)$. Badania wpływu profilu części trzonowej gumy na wyznaczone wartości sił wciągania w funkcji zmiennego podciśnienia wykazały, że przy penetracjach strzyków 50 i $62 \mathrm{~mm}$ (najczęściej występujące długości strzyków u dojonych krów) najmniejszą siłę wciągania zaobserwowano w przypadku gumy o przekroju trójkątnym, nieco większą o przekroju kwadratowym, zaś największą siłę wciągania generują gumy okrągłe i owalne.
\end{abstract}

Słowa kluczowe: dój mechaniczny, kubek udojowy, gumy strzykowe, siły wciągania strzyka

Identification data Authors:

Wiercioch Marian

Adam Luberański

Krzysztof Lejman

Matgorzata Fugol

Hubert Prask https://orcid.org/0000-0001-5201-6301

https://orcid.org/0000-0002-6902-7645

https://orcid.org/0000-0002-7223-6595

https://orcid.org/0000-0002-1080-8711

https://orcid.org/0000-0002-6651-0172 